terol. Arch Biochem Biophys 207:427

13. Wolfe LS, Ng Ying Kin NMK, Baker RR 1981 Batten disease and related disorders: new findings on the chemistry of the storage material. In: Callahan JW, Lowden JA (eds) Lysosomes and Lysosomal Storage Diseases. Raven Press, New York, pp 315-330

14. Wolfe LS, Ng Ying Kin NMK, Baker RR, Carpenter S, Andermann F 1977 Identification of Retinoyl complexes as the autofluorescent component of the neuronal storage material in Batten disease. Science 195:1360

15. Wolfe LS, Ng Ying Kin NMK, Palo J, Haltia M 1982 Raised levels of cerebral cortex dolichols in Alzheimers disease. Lancet 1:99
16. Wolfe LS, Ng Ying Kin NMK, Palo J, Haltia M 1983 Dolichols in brain and urinary sediment in neuronal ceroid lipofuscinosis. Neurology 33:103

17. Wong TK Lennarz WJ 1982 The site of biosynthesis and intracellular deposition of dolichol in rat liver. J Biol Chem 257:6619

18. Zeman W 1974 Studies in the neuronal ceroid-lipofuscinosis. J Neuropathol Exp Neurol 33:1

19. Zeman W, Donahue S, Dyken P, Green J 1970 The neuronal ceroid-lipofuscinosis (Batten-Vogt syndrome). In: Vinken PJ, Bruyn GW (eds) Handbook of Clinical Neurology, Vol 10. North Holland, Amsterdam, pp 588-679

\title{
N-Acetylneuramin Lactose Sulfate: A Newly Identified Nutrient in Milk
}

\author{
JOHN A. STURMAN, YONG Y. LIN, TETSUO HIGUCHI, AND J. H. FELLMAN
}

Departments of Pathological Biochemistry and of Human Development and Nutrition, Institute for Basic Research in Developmental Disabilities, Staten Island, New York 10314 [J.A.S., Y.Y.L.]; JEOL (U.S.A.), Inc., Cranford, New Jersey 07016 (T.H.); and School of Medicine, Department of Biochemistry, Oregon Health Sciences University, Portland, Oregon 97201 [J.H.F.]

\begin{abstract}
The identity of a sulfate ester in rat milk has been determined to be $\mathrm{N}$-acetylneuramin lactose sulfate. This sulfate ester is present in rat mammary tissue and in human milk. The presence of this compound offers an explanation for the simultaneous delivery of sulfate and calcium via the milk, two essential nutrients in early life, without precipitation of calcium sulfate in the milk. $\mathbf{N}$ acetylneuramin lactose sulfate is hydrolyzed in the gut of the neonate and absorbed as inorganic sulfate. This is the first report suggesting that this ester may be of nutritional importance. (Pediatr Res 19: 216-219, 1985)
\end{abstract}

The delivery of nutrients to dependent offspring via the milk is an important process for normal development, although many of the constituents remain unidentified at present. Even in man, where the greatest research effort has been expended, many nutrients and growth factors have yet to be identified. This situation is exemplified by the different metabolic responses in human infants fed human milk or a variety of synthetic formulas based on partially purified proteins $(1-8)$. In general the concentration of most amino acids in plasma and urine is greater in infants fed formulas than in those fed human milk, although taurine is a notable exception. The role of taurine in the nervous system, especially during development, has received much attention during the last decade, especially since the discovery that cats and kittens fed synthetic diets containing partially purified proteins suffered from retinal and tapetal degeneration (9-18).

Received March 23, 1984; accepted October 16, 1984.

Correspondence to Dr. John A. Sturman, Developmental Neurochemistry Laboratory, Department of Pathological Biochemistry, Institute for Developmental Disabilities, 1050 Forest Hill Road, Staten Island, NY 10314.

Supported by the Office of Mental Retardation and Developmental Disabilities of the State of New York.
More recently it has been shown that rhesus monkeys raised on a synthetic human infant formula have damaged cone photoreceptors (19). Radioactive taurine injected intraperitoneally into lactating female rats is secreted into the milk, and allows estimation of the contribution of milk taurine to the brain and other tissues $(20,21)$. During these investigations milk was found to contain a radioactive sulfur-containing compound which was eluted from an ion exchange column in the proximity of the solvent front (Fig. 1). Most tissues and fluids contained only radioactive taurine, but in a few, such as plasma, urine, and feces, radioactive inorganic sulfate was also detected. A radioactive compound found in milk was distinguished from inorganic sulfate by the fact that a negligible portion was precipitated by barium chloride. Small amounts of the compound, along with inorganic sulfate, were detected in the viscera of the suckling pups. The identification of this compound as $\mathrm{N}$-acetylneuramin lactose sulfate and a discussion of its potential nutritional role is the subject of this communication.

\section{MATERIALS AND METHODS}

Lactating rats were injected intraperitoneally with $\left[{ }^{35} \mathrm{~S}\right]$ taurine (specific activity $51 \mathrm{mCi} / \mathrm{mmol}$ ) or $\left[{ }^{35} \mathrm{~S}\right]$ inorganic sulfate (specific activity $78 \mathrm{mCi} / \mathrm{mmol}$ ). Both radiochemicals were purchased from Amersham. The experiments with $\left[{ }^{35} \mathrm{~S}\right]$ taurine have been previously described in detail (22). The experiments with $\left[{ }^{35} \mathrm{~S}\right]$ inorganic sulfate were performed as follows: Four lactating dams were injected with $500 \mu \mathrm{Ci}\left[{ }^{35}\right.$ S] inorganic sulfate on days 3 and 4 after birth, and milk samples obtained on days 4,5 , and 6 (on day 4 the sample was obtained $24 \mathrm{~h}$ after the first injection, and prior to the second injection; on day 5 the sample was obtained $24 \mathrm{~h}$ after the second injection). After the third milking, mother and pups were killed and liver, brain, and mammary tissue dissected from the mother, and liver, brain, stomach milk, and carcass retained from the pups for later analysis. Milk samples were obtained after separating the pups from the mother for $4 \mathrm{~h}$, 


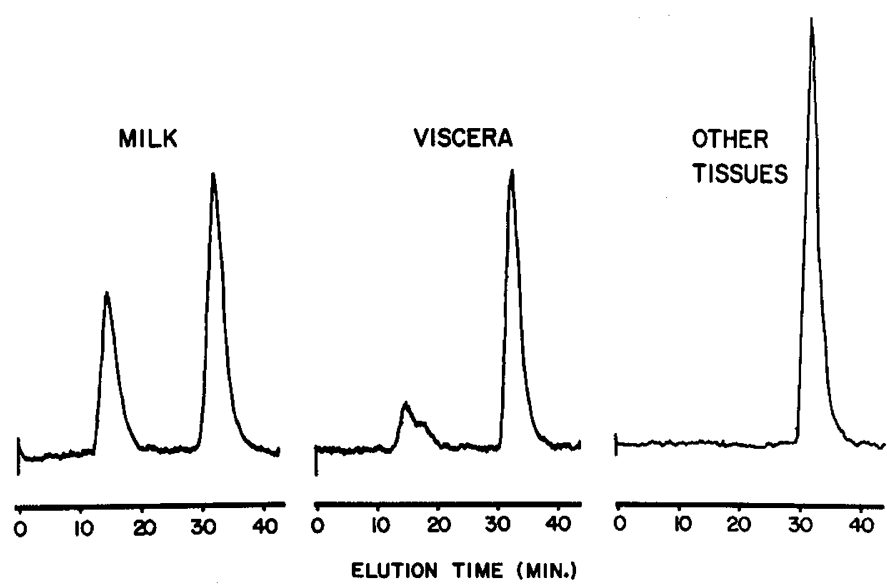

Fig. 1. Flow-cell chromatograms of extracts of milk, viscera, and other tissues (e.g. brain, muscles, kidney, etc.) from rat pups suckling dams injected with $\left[{ }^{35}\right.$ S $]$ taurine. $\left[{ }^{35} \mathrm{~S}\right]$ Taurine is present in all extracts, eluted at $30 \mathrm{~min}$. The second labelled compound in milk has been identified as $\mathrm{N}$-acetylneuramin lactose sulfate. A small amount of this compound is present in viscera, along with labelled inorganic sulfate. Reproduced from Reference 20 with permission.

and after the dams were anesthetized (10 mg sodium pentobarbital) and injected with oxytocin ( $0.5 \mathrm{IU}$ in $0.5 \mathrm{ml} 0.9 \%$ saline). Drops of milk were gently squeezed from the nipples and aspirated into a $1 \mathrm{ml}$ syringe. Using this method, samples of 2 to 3 $\mathrm{ml}$ could be obtained in $30 \mathrm{~min}$. Human milk samples were obtained from anonymous donors courtesy of LaLeche League of Staten Island. Milk was deproteinized with 5 vol $10 \%$ trichloroacetic acid, centrifuged at $15,000 \times g$ for $30 \mathrm{~min}$, and the supernatant fluid filtered to ensure that no fat was transferred. Rat tissues were prepared in the same way after homogenizing with 5 vol $10 \%$ trichloroacetic acid. The extracts were analyzed using an automatic amino acid analyzer, and radioactivity monitored by passing the effluent from the column through a flowcell adapter in a flow-monitor system. Other portions of the supernatant fluids were extracted twice with equal volumes of ether to remove excess trichloroacetic acid and any remaining fat, and applied to a $7 \times 0.8 \mathrm{~cm}$ column of Biorex-5 anion exchange resin and eluted as follows: $6 \mathrm{ml}$ water (designated fraction 1) which would contain compounds such as taurine, thiotaurine, and sulfocysteamine; a $3 \mathrm{ml}$ water wash, followed by $10 \mathrm{ml} 0.5 \mathrm{~N} \mathrm{HCl}$ (designated fraction 2) which would contain compounds such as isethionate, sulfite, cysteic acid, sulfocysteine, and the sulfate ester reported herein; finally $10 \mathrm{ml} 2 \mathrm{~N}$ $\mathrm{HCl}$ (designated fraction 3 ) which would contain inorganic sulfate. Further purification of fractions was performed by high voltage electrophoresis in formic: acetic acid, $\mathrm{pH}$ 1.9, Whatman $3 \mathrm{M}$ paper at $4500 \mathrm{~V}$ for $2 \mathrm{~h}$. The radioactive area was eluted with water and evaporated to dryness. Portions of the residue were applied to a gold tip probe in a Finnigan 4012 mass spectrometer employing ammonia gas chemical ionmization, and later using a JEOL JMS-DX300 mass spectrometer with fast atomic bombardment attachment.

\section{RESULTS}

The unknown sulfur-containing compound produced in milk of lactating dams injected with $\left[{ }^{35}\right.$ S]taurine (Fig. 1) was partially purified by collecting fraction 2 as described above. The radioactive compound retained its original position when rechromatographed on the amino acid analyzer and on the anion exchange column. Following acid hydrolysis $\left(2 \mathrm{~N} \mathrm{HCl}\right.$ at $100^{\circ} \mathrm{C}$ for 10 $\mathrm{min}$ ), the radioactivity now appeared in fraction 3 after chromatography on the anion exchange column, and was all precipitated by barium chloride, indicating that it was now present as inorganic sulfate. Extracts of the viscera from pups that were suckling the dams injected with $\left[{ }^{35} \mathrm{~S}\right]$ taurine contained two radioactive compounds in addition to taurine when chromatographed on the amino acid analyzer, one of which, inorganic sulfate, was removed by treatment with barium chloride. Radioactivity appeared in fractions 2 and 3 when chromatographed on the anion exchange column, suggesting that both the unknown compound and inorganic sulfate were present. Analyses of other tissues (brain, liver, kidney, heart) of the pups detected only radioactive taurine. The unknown compound was not detected in any tissues from the dam, except mammary tissue, suggesting that this compound is probably synthesized by the mammary gland, and that it was $\mathrm{N}$-acetylneuramin lactose sulfate which has previously been identified in rat mammary tissue (22-24). These studies suggested that this compound was a sulfate ester.

A second series of experiments was conducted in which $\left[{ }^{35} \mathrm{~S}\right]$ inorganic sulfate was injected into lactating rats, and samples collected as before. Radioactivity secreted in milk was proportionately much greater than had been observed with the $\left[{ }^{35} \mathrm{~S}\right]$ taurine experiments, and was predominantly present in fraction 2 (Table 1). Radioactivity in the mammary gland was present in both fractions 2 and 3, whereas in maternal liver and brain it was predominantly in fraction 3 (Table 1). In the pups, approximately half of the radioactivity in stomach milk was in fraction 2 and half was in fraction 3 , whereas in liver, brain, and carcass it was present only in fraction 3 . The labeled compound in fraction 2 had the same characteristics as described above, and was further purified by high voltage electrophoresis.

Samples of rat milk at 5, 6, and 21 days after birth were chromatographed as described above, and fraction 2 collected and hydrolyzed. Total inorganic sulfate was measured to determine the amount of $\mathrm{N}$-acetylneuramin lactose sulfate present in

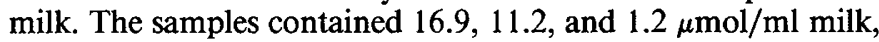
respectively. Five samples of late human milk (more than $8 \mathrm{wk}$ after birth) were processed in an identical fashion and the content of $\mathrm{N}$-acetylneuramin lactose sulfate calculated in this way ranged from undetectable to $1.0 \mu \mathrm{mol} / \mathrm{ml} \mathrm{milk}$. It is of note that fraction 3 (which would contain free inorganic sulfate) collected from rat milk and human milk did not contain any detectable inorganic sulfate.

This compound produced a complex mass spectrum by direct probe in the chemical ionization mode using ammonia as reagent gas. Although no molecular ion could be detected, fragment ions characteristic of $\mathrm{N}$-acetylneuraminic acid, $\mathrm{m} / \mathrm{Z}$ 291, 274, 214, 196, 170 (Y.Y. Lin, unpublished observations) and of glucose and galactose, ${ }^{m} / Z 180,162,144,126$, were observed.

A further attempt was made to detect a molecular ion using fast atomic bombardment ionization in the negative ion mode and, although a molecular ion for the sulfate ester could not be

Table 1. Distribution of radioactivity in rat tissues after injection of $\left[{ }^{35}\right.$ S]inorganic sulfate

\begin{tabular}{|c|c|c|c|}
\hline Tissue & $10^{3} \mathrm{dpm} / \mathrm{g}(\mathrm{ml})$ & $\%$ Fraction $2 *$ & $\%$ Fraction $3 \dagger$ \\
\hline Milk day 4 & $6419 \pm 701$ & 98 & 2 \\
\hline day 5 & $5320 \pm 704$ & 99 & 1 \\
\hline day 6 & $5151 \pm 766$ & 99 & 1 \\
\hline Mammary gland & $662 \pm 80$ & 72 & 28 \\
\hline Maternal liver & $247 \pm 66$ & 11 & 89 \\
\hline Maternal brain & $21 \pm 2$ & 0 & 100 \\
\hline Pup stomach milk & $131 \pm 32$ & 51 & 49 \\
\hline Pup liver & $35 \pm 7$ & 0 & 100 \\
\hline Pup brain & $1.1 \pm 0.4$ & 0 & 100 \\
\hline Pup carcass & $7 \pm 3$ & 0 & 100 \\
\hline
\end{tabular}

Results represent the mean \pm SD from four lactating rats and from eight pups (two from each mother).

* Radioactivity in fraction 2 is $\mathrm{N}$-acetylneuramin lactose sulfate. Upon hydrolysis and rechromatography, all radioactivity appears in fraction 3 .

$\dagger$ Radioactivity in fraction 3 is inorganic sulfate. Upon treatment with excess barium chloride and rechromatography, all radioactivity is removed. 

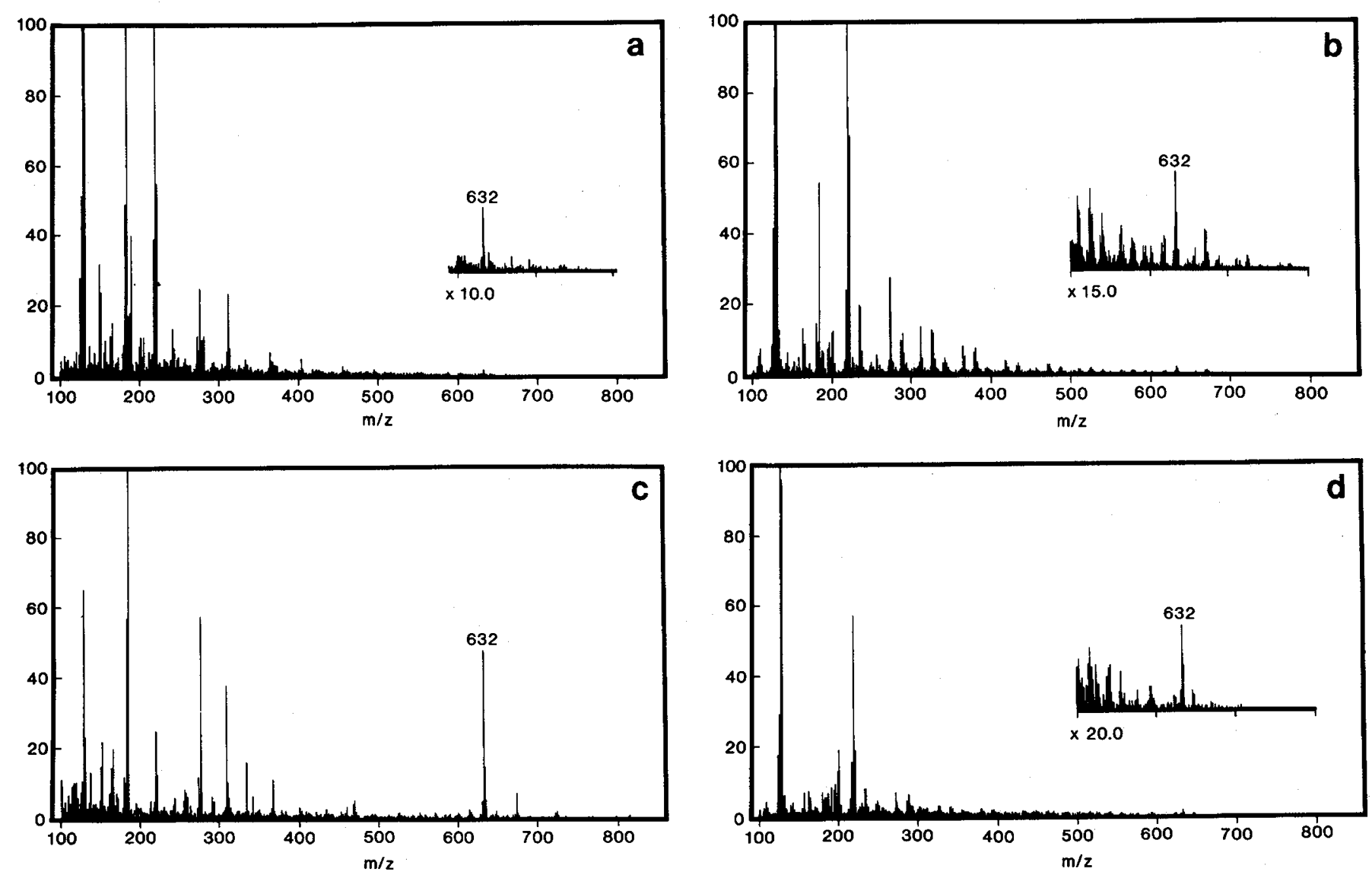

Fig. 2. Mass spectra obtained using fast atomic bombardment ionization in the negative ion made of $(a)$ the sulfate ester from rat milk, $(b)$ the sulfate ester from rat mammary tissue, $(c)$ authentic $\mathrm{N}$-acetylneuramin lactose, $(d)$ the same fraction from human milk.

obtained, a fragment of $\mathrm{m} / \mathrm{Z} 632$, due to $(\mathrm{M}-\mathrm{H})^{-}$ion of $\mathrm{N}$ acetylneuramin lactose was obtained (Fig. 2). The compound isolated from rat milk and from rat mammary tissue produced this fragment. This was compared with the spectrum of authentic sialyl lactose (Fig. $2 c$ ), which also showed the presence of a (M$\mathrm{H})^{-}$ion at $^{\mathrm{m}} / \mathrm{Z} 632$.

The clear evidence that this compound is a sulfate ester taken in conjunction with the mass spectrometric evidence for the identity of $\mathrm{N}$-acetylneuramin lactose is strong evidence that the compound in milk and mammary tissue is $\mathrm{N}$-acetylneuramin lactose sulfate. Finally, this compound has been previously detected and identified by chemical methods in rat mammary gland tissue (22-26).

A sample of human milk was processed exactly as described for rat milk and the mass spectrum obtained (Fig. $2 d$ ). This spectrum also showed the presence of a fragment with $\mathrm{m} / \mathrm{Z} 632$, indicating that human milk resembles rat milk in this respect.

\section{DISCUSSION}

The present results identify $\mathrm{N}$-acetylneuramin lactose sulfate as a component of rat milk, a finding in keeping with results of previous studies which had identified this compound in lactating rat mammary gland and had shown this tissue to be the biosynthetic source $(22-26)$. $\left[{ }^{35}\right.$ S]Inorganic sulfate is readily incorporated into $\mathrm{N}$-acetylneuramin lactose sulfate in vivo, and secreted in the milk. In mammary gland, two-thirds of the trichloroacetic acid-soluble radioactivity is present as $\mathrm{N}$-acetylneuramin lactose sulfate and one-third is present as inorganic sulfate, whereas maternal liver and brain contain predominantly inorganic sulfate. In milk, virtually all radioactivity is present as $\mathrm{N}$-acetylneuramin lactose sulfate. These results suggest that this compound is synthesized by the lactating mammary gland for the sole purpose of secretion into the milk, and that free inorganic sulfate is not secreted into the milk. Stomach milk of the pups contains half of the radioactivity present in $\mathrm{N}$-acetylneuramin lactose sulfate and half in free inorganic sulfate, indicating that hydrolysis is taking place in the stomach. Only free inorganic sulfate was found in the pup's liver, brain, and carcass, suggesting that free inorganic sulfate is absorbed from the gut and utilized for synthesis of such trichloroacetic acid-insoluble compounds as sulfated mucopolysaccharides and sulfated glycoproteins by the rapidly growing pup. It has been demonstrated that the entire length of the small intestine and colon of young infant mice accumulates sulfate whereas in the mature mouse (postweaning) accumulation of sulfate only occurs in the last quarter of the small intestine (27).

Sulfate is not an essential nutrient in mature mammals since the major terminal metabolite of sulfur amino acid catabolism is sulfate. The recent investigation of the ontogeny of the crucial rate-limiting enzyme, cysteine dioxygenase, has revealed that activity of this enzyme only slowly emerges in rat postnatal development (28). There was no detectable activity in fetal and 2 -day-old rat pup and the activity rises slowly until the 28th postnatal day when it reaches adult levels. At the 12th postnatal day the activity of the enzyme is a small fraction of the adult. Thus sulfate apparently cannot be synthesized by the neonatal rat and may be an essential nutrient early in life. This developmental pattern probably results from the heavy metabolic demands upon methionine and cysteine for protein synthesis at this stage of rapid growth, relying on the milk to provide terminal catabolites such as sulfate and taurine. The secretion of sulfate in the milk as the organic ester, $\mathrm{N}$-acetylneuramin lactose sulfate, is a uniquely useful way to provide this nutrient. Furthermore, $\mathrm{N}$-acetylneuramin lactose sulfate is present in mammary tissue in the greatest concentration at the beginning of lactation and disappears by the 18 th day of lactation (25), at which time substantial cysteine dioxygenase activity appears in liver (28), 
augmenting the hypothesis that $\mathrm{N}$-acetylneuramin lactose sulfate serves a specific nutritional function during development. Milk is also the sole source of calcium ions for bone formation in the postnatal period, the dissociation constant of calcium ions with sulfate ions is low, and calcium sulfate would precipitate unless the sulfate were supplied in an unionized form. N-acetylneuramin lactose sulfate fulfills this requirement and is easily hydrolyzed in the gut to free sulfate for absorption and further utilization. The amount present in rat milk indicates that this sulfate ester is a substantial constituent, especially at the beginning of lactation, in accord with its having a nutritional role. It should be noted here that while free sulfate is present in the blood of lactating dams, it is not present in their milk, presumably for the reason stated above. We also hypothesize that the $\mathrm{N}$-acetylneuramic acid portion of the molecule may have been selected for this purpose because it, too, has a nutritional role. However, the literature describing the ontogeny of $\mathrm{N}$-acetylneuraminic acid biosynthesis provides no evidence for or against this hypothesis which will be subject of our further investigations. Finally, the presence of $\mathrm{N}$-acetylneuramin lactose sulfate in human milk suggests that the possible role of this compound in human infant nutrition cannot be ignored, for the same criteria pertain, namely: delivery of calcium via the milk and the nutritional need for sulfate by the infant. Although no information is available on the ontogeny of cysteine dioxygenase in man, it has been shown that development of cystathionase activity is a postnatal phenomenon (29), and that activity of cysteinesulfinic acid decarboxylase is very low in all human tissue (30), so biosynthesis of inorganic sulfate is likely to be restricted. No data are available on the sulfate balance of newborn infants, but it is known that older infants excrete inorganic sulfate in their urine in proportion to the amount of protein ingested. Thus the nutritional importance of $\mathrm{N}$-acetylneuramin lactose is probably greatest in the immediate postnatal period for both man and rat.

Acknowledgments. We are grateful for the technical assistance of Steven Kastin who performed some of the experiments while working as a summer student.

\section{REFERENCES}

1. Gaull GE, Rassin DK, Raiha NCR, Heinonen K 1977 Milk protein quantity and quality in low-birth weight infants. III. Effects on sulfur amino acids in plasma and urine. J Pediatr 90:348-355

2. Jarvenpaa A-L, Raiha NCR, Rassin DK, Gaull GE 1983 Feeding the low birth-weight infant: I. Taurine and cholesterol supplementation of formula does not affect growth and metabolism. Pediatrics 71:171-178

3. Jarvenpaa A-L, Raiha NCR, Rassin DK, Gaull GE 1982 Milk protein quantity and quality in the term infant. I. Metabolic responses and effects on growth Pediatrics 70:214-220

4. Jarvenpaa A-L, Rassin DK, Raiha NCR, Gaull GE 1982 Milk protein quantity and quality in the term infant. II. Effects on acidic and neutral amino acids. Pediatrics 70:221-230

5. Raiha NCR, Heinonen K, Rassin DK, Gaull GE 1976 Milk protein quantity and quality in low-birth-weight infants. I. Metabolic responses and effects on growth. Pediatrics 57:659-674

6. Rassin DK, Gaull GE, Heinonen K, Raiha NCR 1977 Milk protein quantity and quality in low-birth-weight infants. II. Effects on selected aliphatic amino acids in plasma and urine. Pediatrics 59:407-422

7. Rassin DK, Gaull GE, Raiha NCR, Heinonen K 1977 Milk protein quantity and quality in low-birth-weight infants. IV. Effects on phenylalanine in plasma and urine. J Pediatr 90:356-360

8. Rassin DK, Gaull GE, Jarvenpaa A-L, Raiha NCR 1983 Feeding the lowbirth-weight infant. II. Effects of taurine and cholesterol supplementation on amino acids and cholesterol. Pediatrics 71:179-186

9. Anderson PA, Baker DH, Corbin JE, Helper LC 1979 Biochemical lesions associated with taurine deficiency in the cat. J Anim Sci 49:1227-1234

10. Berson EL, Hayes KC, Rabin AR, Schmidt SY, Watson G 1976 Retinal degeneration in cats fed casein. II. Supplementation with methionine, cysteine, or taurine. Invest Ophthalmol 15:52-58

11. Hayes KC, Carey RE, Schmidt SY 1975 Retinal degeneration associated with taurine deficiency in the cat. Science 188:949-951

12. Schmidt SY, Berson EL, Hayes KC 1976 Retinal degeneration in cats fed casein. 1. Taurine deficiency. Invest Ophthalmol 15:45-52

13. Schmidt SY, Berson EL, Huang WG 1977 Retinal degeneration in cats fed casein. III. Taurine deficiency and ERG amplitudes. Invest Ophthalmol Vi Sci 16:673-678

14. Sturman JA, Hayes KC 1980 The biology of taurine in nutrition and development. Adv Nutr Res 3:231-299

15. Sturman JA, Rassin DK, Gaull GE Taurine in the development of the central nervous system. In: Barbeau A, Huxtable RJ (eds) Taurine and Neurological Disorders. Raven Press, New York, pp 49-71

16. Sturman JA, Rassin DK, Gaull GE 1977 Taurine in development. Life Sci 21:1-22

17. Sturman JA, Wen GY, Wisniewski HM, Hayes KC 1981 Histochemical localization of zinc in the feline tapetum: Effect of taurine depletion. Histochemistry $72 \cdot 341-350$

18. Wen GY, Sturman JA, Wisniewski HM, Lidsky AA, Cornwell AC, Hayes KC 1979 Tapetum disorganization in taurine-depleted rats. Invest Ophthalmo Vis Sci 18:1201-1206

19. Sturman JA, Wen GY, Wisniewski HM, Neuringer MD 1984 Retinal degeneration in primates raised on a synthetic infant formula. Int $J$ Dev Neurosci 2:121-129

20. Sturman JA 1981 Origin of taurine in developing rat brain. Dev Brain Res 2:111-128

21. Sturman JA, Rassin DK, Gaull GE 1977 Taurine in developing cat brain Transfer of $\left({ }^{35}\right.$ S)taurine to pups via the milk. Pediatr Res 11:28-33

22. Barra WC, Caputto $R 1965$ Isolation and identification of a lactose sulphate ester from rat mammary gland. Biochim Biophys Acta 101:367-369

23. Carlson DM, Jourdian GW, Roseman S 1973 The sialic acids. XIV. Synthesis of sialyl-lactose by a sialytransferase from rat mammary gland. J Biol Chem 248:5742-5750

24. Choi HU, Carubelli R 1968 Neuramin-lactose, neuramin-lactose sulfate, and lactose sulfate from rat mammary glands. Isolation, purification, and permethylation studies. Biochemistry 7:4423-4430

25. Carubelli R, Ryan LC, Trucco RE, Caputto R 1961 Neuramin-lactose sulfate a new compound isolated from the mammary gland of rats. $J$ Biol Chem 36:2381-2388

26. Ryan LC, Carubelli R, Caputto R, Trucco RE 1965 Studies on the structure of neuramin-lactose sulfate. Biochim Biophys Acta 101:252-258

27. Batt ER 1969 Sulfate accumulation by mouse intestine: Influence of age and other factors. Am J Physiol 217:1101-1104

28. Hosokawa Y, Yamaguchi K, Kohashi N, Kori Y, Fujii O, Ueda I 1980 Immaturity of the enzyme activity and the response to inducers of rat liver cysteine dioxygenase during development. J Biochem 88:3890-394

29. Sturman JA, Gaull GE, Raiha NCR 1970 Absence of cystathionase in human fetal liver: is cysteine essential? Science 169:74-76

30. Sturman JA 1981 Cysteine sulfinic acid decarboxylase activity in the mammalian nervous system: absence from axons. J Neurochem 36:304-306 